OECDpublishing

THE SWEDISH TAX ON NITROGEN OXIDE EMISSIONS

LESSONS IN ENVIRONMENTAL POLICY REFORM

OECD ENVIRONMENT POLICY PAPER

December 2013 nº2 


\section{The Swedish Tax on Nitrogen Oxide Emissions}

Lessons in Environmental Policy Reform

S. . . . . .

$x+\pi$

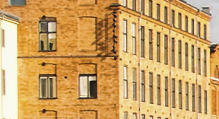

ii 7
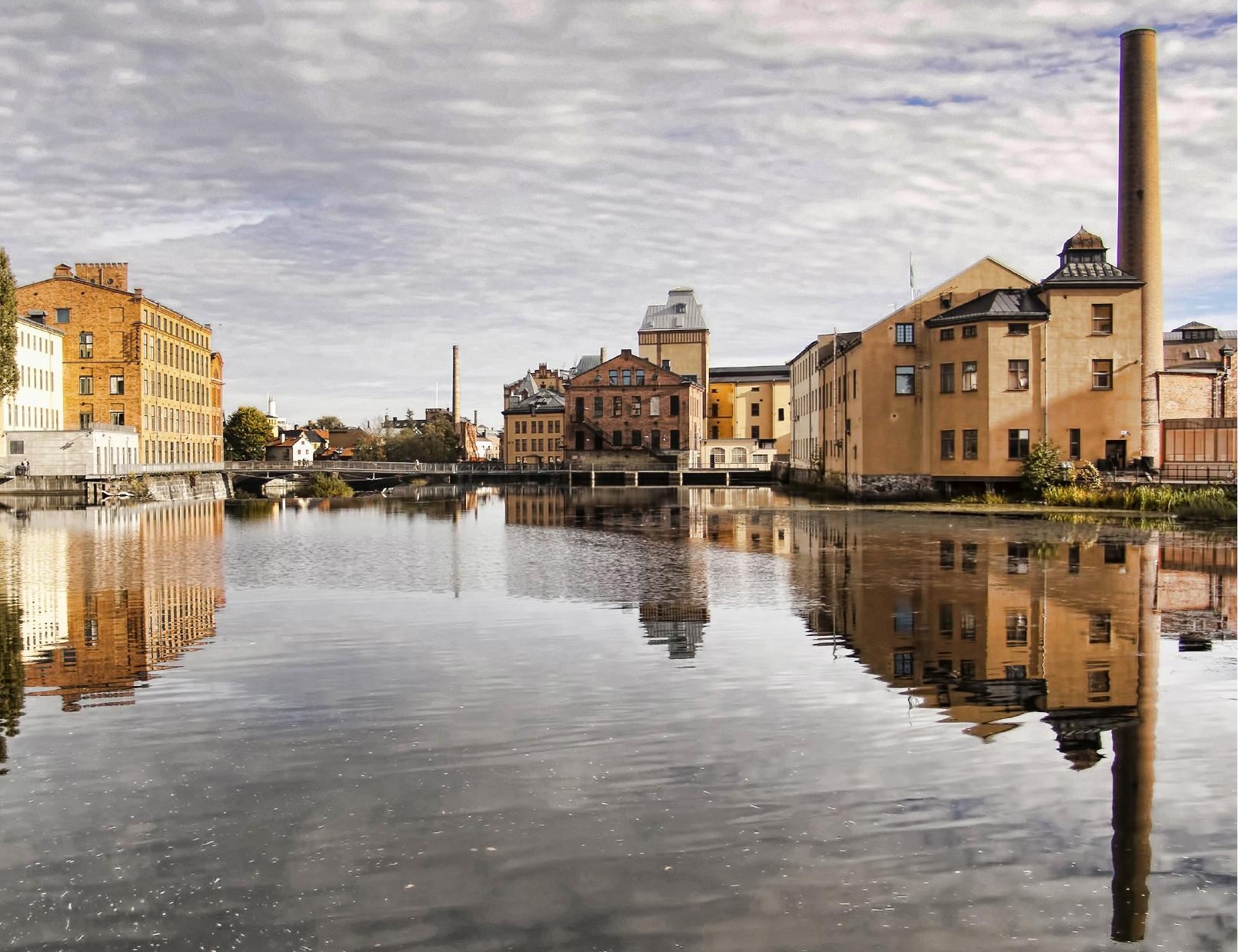

OECD ENVIRONMENT POLICY PAPER NO. 2

DECEMBER 2013

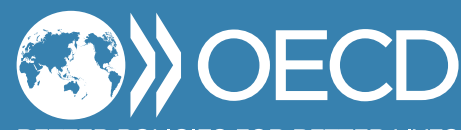




\section{Disclaimers}

The OECD Environmental Policy Papers are published on the responsibility of the SecretaryGeneral of the OECD. The opinions expressed and arguments employed herein do not necessarily reflect the official views of the Organisation or of the governments of its member countries.

This document and any map included herein are without prejudice to the status of or sovereignty over any territory, to the delimitation of international frontiers and boundaries and to the name of any territory, city or area.

\section{Copyright}

You can copy, download or print OECD content for your own use, and you can include excerpts from OECD publications, databases and multimedia products in your own documents, presentations, blogs, websites and teaching materials, provided that suitable acknowledgment of OECD as source and copyright owner is given. All requests for public or commercial use and translation rights should be submitted to rights@oecd.org. Requests for permission to photocopy portions of this material for public or commercial use shall be addressed directly to the Copyright Clearance Center (CCC) at info@copyright.com or the Centre français d'exploitation du droit de copie (CFC) at contact@cfcopies.com. 


\section{The Swedish Tax on Nitrogen Oxide Emissions}

\section{Lessons in Environmental Policy Reform}

OECD ENVIRONMENT POLICY PAPER NO. 2

DECEMBER 2013

\section{Contents}

1. The environmental problem 3

2. The policy challenge: curbing $\mathrm{NO}_{\mathrm{x}}$ emissions in Sweden 4

3. Environmental, social and economic impacts 8

4 Comparison with other countries 19

5. Lessons learned 21

References $\quad 23$

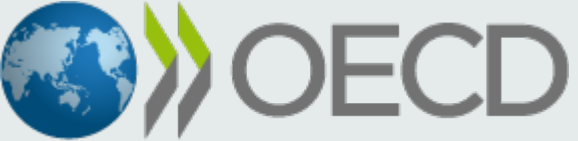




\section{The Swedish Tax on \\ Nitrogen Oxide Emissions}

\section{Lessons in Environmental Policy Reform}

\section{KEY FINDINGS}

\section{The problem}

Sweden was facing a serious soil acidification and water eutrophication problem caused partly by emissions of nitrogen oxides $\left(\mathrm{NO}_{x}\right)$ from combustion processes in transport, industry and power.

\section{The policy response}

In 1992, Sweden introduced a high tax on $\mathrm{NO}_{\mathrm{x}}$ emissions from large combustion sources (e.g. power plants, industrial plants, waste incinerators). The tax was accompanied by a refund according to the amount of energy generated. This ensures that facilities with low $\mathrm{NO}_{x}$ emission intensitites are net beneficiaries of the scheme. Continuous monitoring of emissions was also made mandatory. The tax was designed to accelerate and stimulate investment in advanced combustion and pollution-abatement technologies and as a supplement to existing regulatory measures.

\section{The impact}

A 35\% reduction in $\mathrm{NO}_{x}$ emissions from facilities covered by the tax within 20 months after the implementation of the tax; industry was encouraged to develop cheaper, more efficient technologies; and emission intensities of energy production have been cut by half.

\section{Key messages}

A high emission tax rate can be made politically acceptable by: (1) refunding revenues earned back to the firms affected; and (2) ensuring the policy is well designed. 


\section{The environmental problem}

Soil acidification has been a major political issue in Sweden since the 1980s. With its already naturally acidic soil, Sweden is more sensitive to acid deposition than most other countries. It is therefore one of the countries that has been most affected by acid rain, causing negative impacts to lake and forest ecosystems.

One of the families of gases contributing to acid rain is nitrogen oxides $\left(\mathrm{NO}_{\mathrm{x}}\right)$ : a term used to cover nitric oxide (NO) and nitrogen dioxide $\left(\mathrm{NO}_{2}\right)$. These gases are produced from a reaction between nitrogen and oxygen in the air during combustion, especially at high temperatures such as in engines or power station boilers. $\mathrm{NO}_{\mathrm{x}}$ emissions form nitric acid when dissolved in atmospheric moisture, and this is a component of acid rain (Figure 1). ${ }^{1}$ In addition, nitrogen oxides contribute to the formation of ground-level ozone (smog), which has adverse effects on vegetation and human health (respiratory and cardiovascular problems).

Sweden has taken an aggressive - and largely successful - approach to tackling all the pollutants produced within its borders which contribute to acid rain (mainly sulphur and nitrogen). ${ }^{2}$ This case study describes the approach taken to reduce $\mathrm{NO}_{\mathrm{x}}$ emissions from combustion plants, the challenges encountered and the social, environmental and economic impacts. It concludes by discussing the wider lessons that are raised for other governments seeking to develop similar policy responses.

\section{Figure 1 | Origins of acid rain}

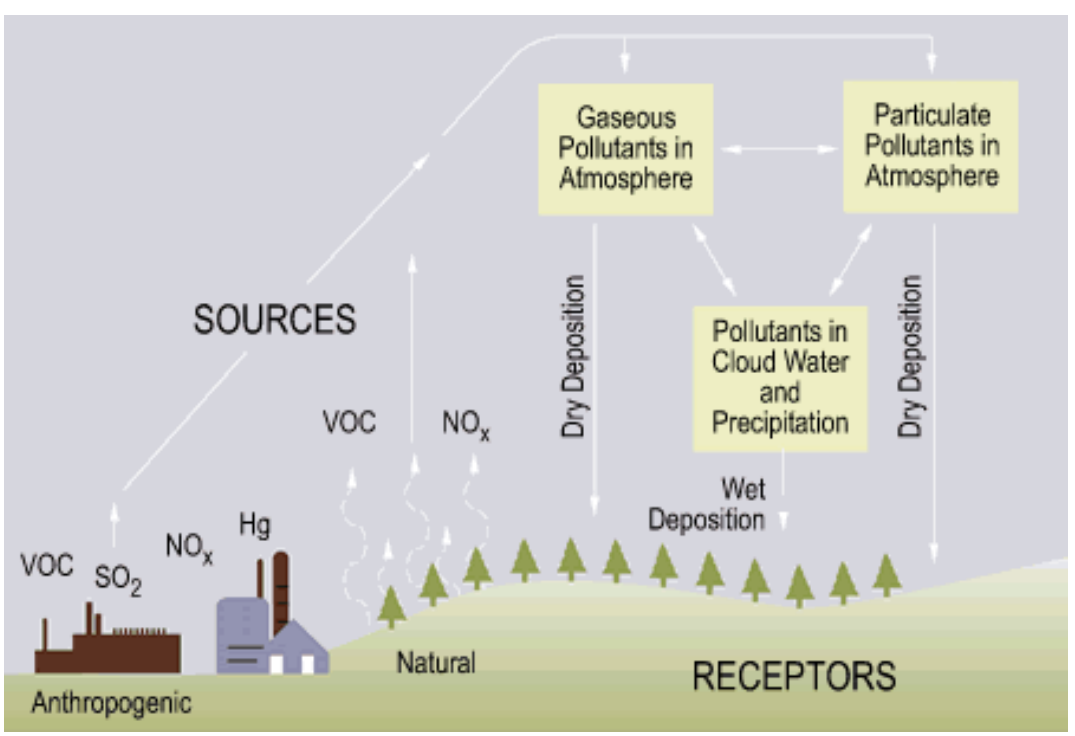

Source: Wikimedia commons, downloaded originally from US EPA website: www.epa.gov/acidrain/images/origins.gif 


\section{The policy challenge:}

\section{Curbing $\mathrm{NO}_{\mathrm{x}}$ emissions in Sweden}

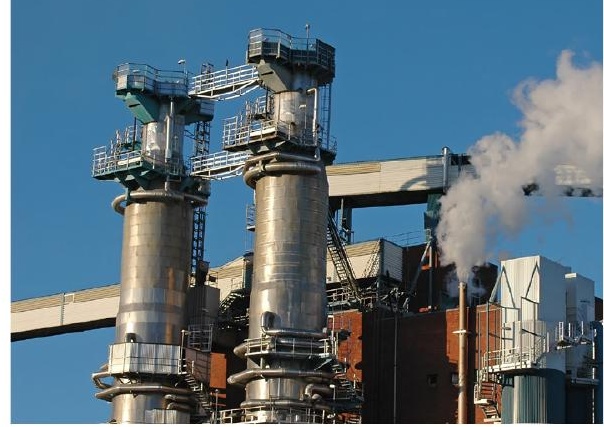

The strong political attention given to environmental problems caused by $\mathrm{NO}_{\mathrm{x}}$ emissions prompted the Swedish Parliament to adopt a strategy in 1985 to reduce overall domestic $\mathrm{NO}_{\mathrm{x}}$ emissions by $30 \%$ by 1995, compared to 1980 levels. The law on environmental protection established $\mathrm{NO}_{\mathrm{x}}$ emission limits as of 1988 for stationary ${ }^{3}$ combustion plants using permits that were non-tradable. However, it soon became clear that these limits would not reduce emissions quickly enough, and in addition the guidelines for how the permits ought to be formulated were not legally binding. The question was how to achieve these large reductions cost effectively and without damaging the competitive basis of the industries involved.

The Swedish Environmental Charges Commission was set up in the late 1980s, tasked with designing effective policies to tackle a range of environmental problems (Box 1). They consulted widely in order to design a politically feasible solution which addressed a number of challenges. The policy chosen for reducing $\mathrm{NO}_{\mathrm{x}}$ from combustion plants was influenced by a number of factors:

- Unlike $\mathrm{CO}_{2}$ and $\mathrm{SO}_{2}$ emissions, which depend to a large extent on the carbon and sulphur content of the fuels combusted, most $\mathrm{NO}_{\mathrm{x}}$ emissions are produced through reactions with nitrogen present in the air (Box 2). This means that while it is possible to tax the carbon and sulphur content of fuels to limit $\mathrm{CO}_{2}$ and $\mathrm{SO}_{2}$ emissions, other means are needed to tackle $\mathrm{NO}_{\mathrm{x}}$ emissions, and emissions will vary significantly depending on the combustion technology employed and the maintenance of the combustion equipment (Box 2) (Sterner and Höglund-Isaksson, 2006).

- $\quad$ The costs of reducing $\mathrm{NO}_{\mathrm{x}}$ emissions vary significantly across producers, and economies of scale and rapid development meant that the flexibility of a market-based instrument was needed. 
- $\quad$ To be an effective deterrent, a high tax rate was needed, but there was likely to be much opposition and lobbying against it by the affected industries; there was also a concern that it would put Swedish firms at a competitive disadvantage compared to foreign producers.

- $\quad$ Given the complexities of $\mathrm{NO}_{\mathrm{x}}$ formation, it is crucial to have direct, continuous monitoring at the plant in order to assess emissions (Box 2). This can be expensive for smaller plants. A tax on all point sources of airborne $\mathrm{NO}_{\mathrm{x}}$ emissions was not feasible because monitoring was too expensive for small units. ${ }^{4}$ But if small units were exempted because of the high monitoring cost, then a high tax levied only on large units could have perverse effects, favouring the operation of small, and usually less efficient units over big ones (Sterner and Höglund-Isaksson, 2006).

\section{Box 1 | Policy by design: the Swedish Environmental Charges Commission}

The Environmental Charges Commission (ECC) was appointed in 1987 and its reports resulted in the introduction of a number of new economic instruments as part of Swedish environmental policy (SOU, 1989). The ECC included representatives from all parliamentary parties, the most relevant ministries, and civil society. The ECC's proposal for the tax on $\mathrm{NO}_{\mathrm{x}}$ emissions was presented for broad public consultation, and a large number of public and private stakeholders expressed their views, mainly in support of the main lines of the proposal. The commission also proposed several other economic instruments, including $\mathrm{CO}_{2}$ and $\mathrm{SO}_{2}$ taxes.

\footnotetext{
4. It was estimated that continuous measuring of $\mathrm{NO}_{x}$ emissions would cost each plant about SEK 350000 (about EUR 37000 ) every year. These high costs made it necessary to limit the tax to relatively large plants. The very largest energy producers were, however, already obliged to have equipment for continuous emission measurements installed, so the $\mathrm{NO}_{\mathrm{x}}$ tax did not imply any additional measurement costs.
} 


\section{The design solution: the Swedish $\mathrm{NO}_{\mathrm{x}}$ emissions tax and refund system}

The policy, voted in by the Swedish Parliament on 1 January 1992, was to impose a high tax on emissions of nitrogen oxides from energy generation at combustion plants. The tax ${ }^{5}$ was set at a rate of $40 \mathrm{SEK}^{6}$ for every kilogramme of $\mathrm{NO}_{\mathrm{x}}$ emitted from any stationary combustion plant producing at least 50 megawatt hours (MWh) of useful energy per year. This corresponds to $6000 \mathrm{USD} /$ tonne, much higher than the hundreds of dollars usual in the US programmes for $\mathrm{NO}_{\mathrm{x}}$ permits (Sterner and Höglund-Isaksson, 2006).

The most innovative feature of this tax, however, was that all the revenue raised (except administration costs) ${ }^{8}$ would be returned to the participating plants in proportion to their production of useful energy. This means that firms emitting low volumes of $\mathrm{NO}_{\mathrm{x}}$ per unit of energy produced are net beneficiaries of the scheme - only firms with large $\mathrm{NO}_{\mathrm{x}}$ emissions per energy unit are net tax payers. This feature of the system encourages the targeted plants to reduce their emissions of nitrogen oxides per unit of energy to the lowest possible level and avoids distorting the pattern of competition between those plants subject to the $\mathrm{NO}_{\mathrm{x}}$ tax and those that are not (SEPA, 2006). Another important feature of the tax was that it was based on mandatory continuous monitoring of emissions.

Initially, about 200 plants producing more than 50 GWh of usable energy per year were regulated by this tax. In the following three years, average emissions per unit of useful energy produced fell by $40 \%$ among these plants. Its effectiveness, coupled with falling monitoring costs, led to extensions of the system, first in 1996 to about 270 plants producing at least $40 \mathrm{MWh}$ of useful energy per year; and then from 1997 onwards, to about 400 plants producing at least 25 MWh of useful energy per year. ${ }^{9}$ Today, all stationary combustion plants producing more than $25 \mathrm{MWh}$ - whether for power and heat production, chemical production, waste incineration, metal manufacturing, pulp and paper, food and wood industry - are subject to the $\mathrm{NO}_{\mathrm{x}}$ tax.

5. This levy is often referred to as a "charge", but according to OECD definitions, it is actually a tax; i.e. an "unrequited payment to general government" (OECD Glossary of Tax Terms, available at www.oecd.org/ctp/glossaryoftaxterms.htm).

6. This tax rate was based on an estimate of the marginal costs of abatement measures that were expected to trigger an emission reduction of some 5 000-7 000 tonnes $\mathrm{NO}_{x}$ per year - the amount necessary to reduce $\mathrm{NO}_{\mathrm{x}}$ emissions by 30\% between 1980 and 1995 .

7. "Useful energy produced" has been accepted as a relevant and neutral yardstick for measuring output from this heterogeneous group of industries since the main goal is to affect combustion technologies. For power plants and district heating plants it is equal to the energy sold. For other industries, the energy is defined as steam, hot water or electricity produced in the boiler and used in production processes or heating of factory buildings (Sterner and Höglund-Isaksson, 2006).

8. SEPA, the administrator of the scheme, stated that the administrative costs were about 0.7\% of the total tax revenue (SEPA, 2003).

9. The EU Directive on Large Combustion Plants specifies emission limits for several air pollutants and a requirement to continuously monitor concentrations of $\mathrm{SO}_{2}$, dust and $\mathrm{NO}_{x}$ in flue gases. All combustion plants with a thermal input of more than $100 \mathrm{MW}$ have been subject to continuous emission monitoring since November 2002. For Sweden, the Directive has no real implications for $\mathrm{NO}_{x}$ emissions since most plants affected are already regulated by the $\mathrm{NO}_{\mathrm{x}}$ tax. 


\section{Box 2 | What causes $\mathbf{N O}_{\mathrm{x}}$ emissions?}

Combustion uses fuel to produce heat. Heat extraction and conversion are the primary functions of combustion units. It is during these steps that the energy is converted into a useful form: piped steam, hot water, hot oil, and/or electricity. Heat requires fuel and an oxidising agent, generally air. Fuel and air are fed, mixed and fired to create a flame, which is propagated throughout the combustion chamber, whose shape, size and materials all can affect $\mathrm{NO}_{x}$ formation and overall efficiency. A conflict may appear between energy-efficiency and $\mathrm{NO}_{x}$ formation, as one way of increasing combustion efficiency is to raise temperature and pressure, which considerably increases the formation of $\mathrm{NO}_{\mathrm{x}}$. Fluidised bed combustors partly overcome this limitation and allow simultaneous efficiency gains and cleaner flue gases. The relationship between combustion parameters and $\mathrm{NO}_{\mathrm{x}}$ formation is highly non-linear and complex. The exhaust gases leave the combustion chamber and may go to post-combustion processes intended to reduce air pollutants (e.g., $\mathrm{NO}_{x}, \mathrm{SO}_{2}, \mathrm{CO}$ and PM). These pollutants can be transformed, precipitated and washed in liquids or deposited as sludge, depending on their nature and concentrations.

\section{Figure 2. Scheme of the main steps in a combustion process}

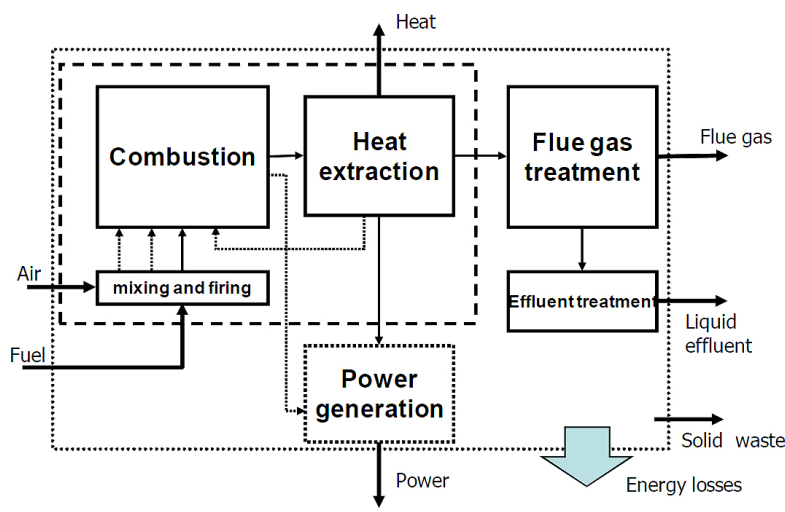

Source: Sterner, T. and B. Turnheim (2008), "Innovation and Diffusion of Environmental Technology", Discussion Paper 2008:02, Resources for the Future, Washington, DC, available at www.rff.org/RFF/Documents/RFF-DP-08-02. pdf.

The cement and lime industry, coke production, and much of the mining industry, refineries, blast-furnaces, glass and isolation material industry, wood board production and processing of biofuels are exempt from the tax, due to concerns about unfeasibly high costs.

From 1 January 2008, the tax rate was increased to SEK 50 (EUR 5.5) per kg of $\mathrm{NO}_{x}$, partly in order to maintain a strong abatement incentive. In 1992, the first year the tax applied, the total revenues were SEK 612 million (SEPA, 2003). In 2011 they amounted to SEK 794 million - about EUR 88 million. 
Many companies started $\mathrm{NO}_{\mathrm{x}}$-reducing projects as soon as the tax was proposed to parliament in 1990, in order to have as low emissions as possible when the tax came into force in January 1992. From 1992 to 2010, $\mathrm{NO}_{\mathrm{x}}$ emissions per unit of energy produced fell by more than 50\% (the red line in Figure 4). The figure also shows how the combined $\mathrm{NO}_{\mathrm{x}}$ emissions from all the plants covered by the tax remained relatively stable over this period, even though the amount of energy produced by these plants more than doubled - partly because of the lowering of the threshold for tax inclusion mentioned above, meaning that more firms became covered by the tax.

\section{Figure 4 | More energy but lower $\mathrm{NO}_{\mathrm{x}}$ emissions from taxed plants}

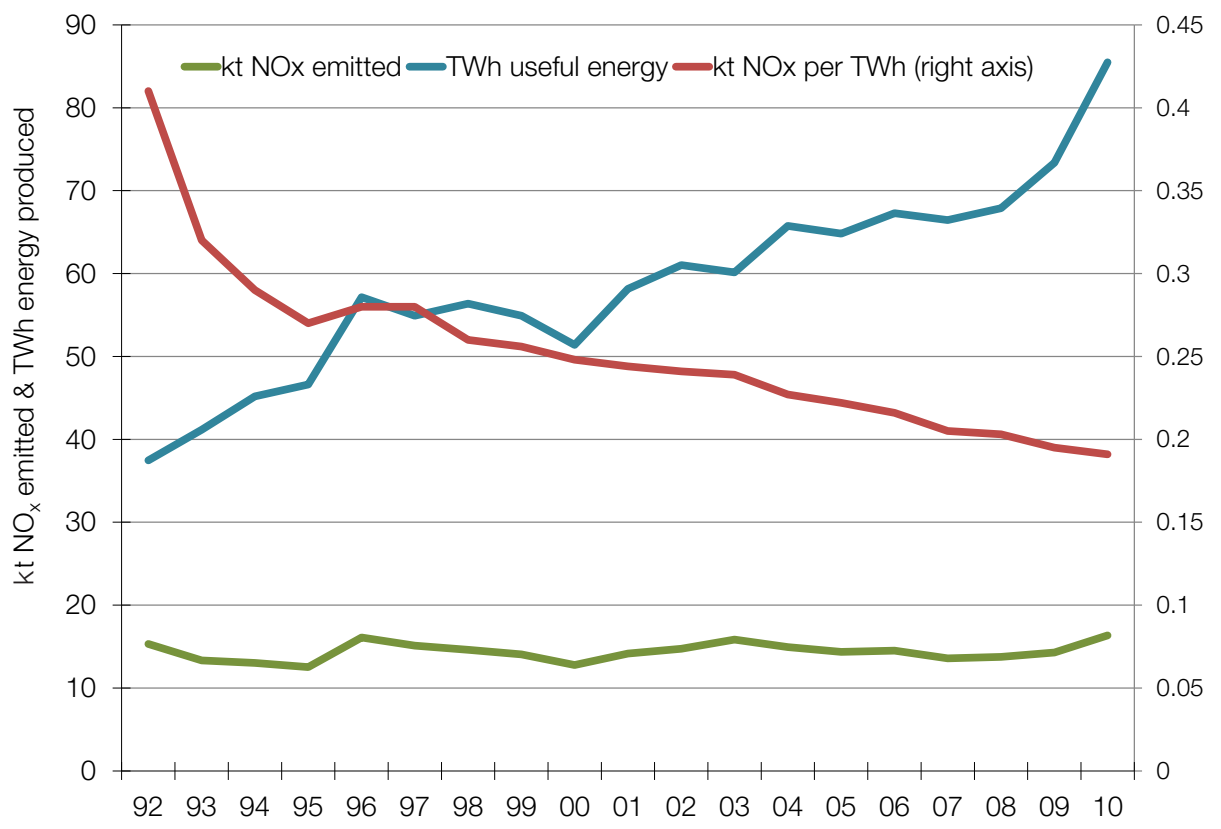

Note: TWh - tera watt hour; kt = kilotonne, i.e. $\uparrow 000$ tonnes

Source: Swedish Environment Protection Agency. 
The management and the operators at the plants have become more focused on reducing $\mathrm{NO}_{\mathrm{x}}$. At one plant the operators are given a salary bonus if $\mathrm{NO}_{\mathrm{x}}$ emissions are low (IISD, undated). The tax seems to have been more effective in reducing emissions intensity than the overlapping regulatory emission standards. Figure 5 shows that by 2001, not only had all the plants complied with their emission limits, ${ }^{10}$ but the $\mathrm{NO}_{\mathrm{x}}$ tax appears to have provided strong incentives for most of the surveyed plants to lower emission intensities well below the limits of the quantitative standards. ${ }^{11}$ This is based on information collected by SEPA (2003) on emission standards and actual emission intensities for 73 plants that were regulated by the $\mathrm{NO}_{\mathrm{x}}$ tax both in 1997 and 2001. The actual emission intensity levels were on average $40 \%$ below the limits specified by the quantitative standards for these plants. Also, actual emission intensities for plants with very generous standards were comparable with emission intensities in plants with considerably stricter limits (OECD, 2010a).

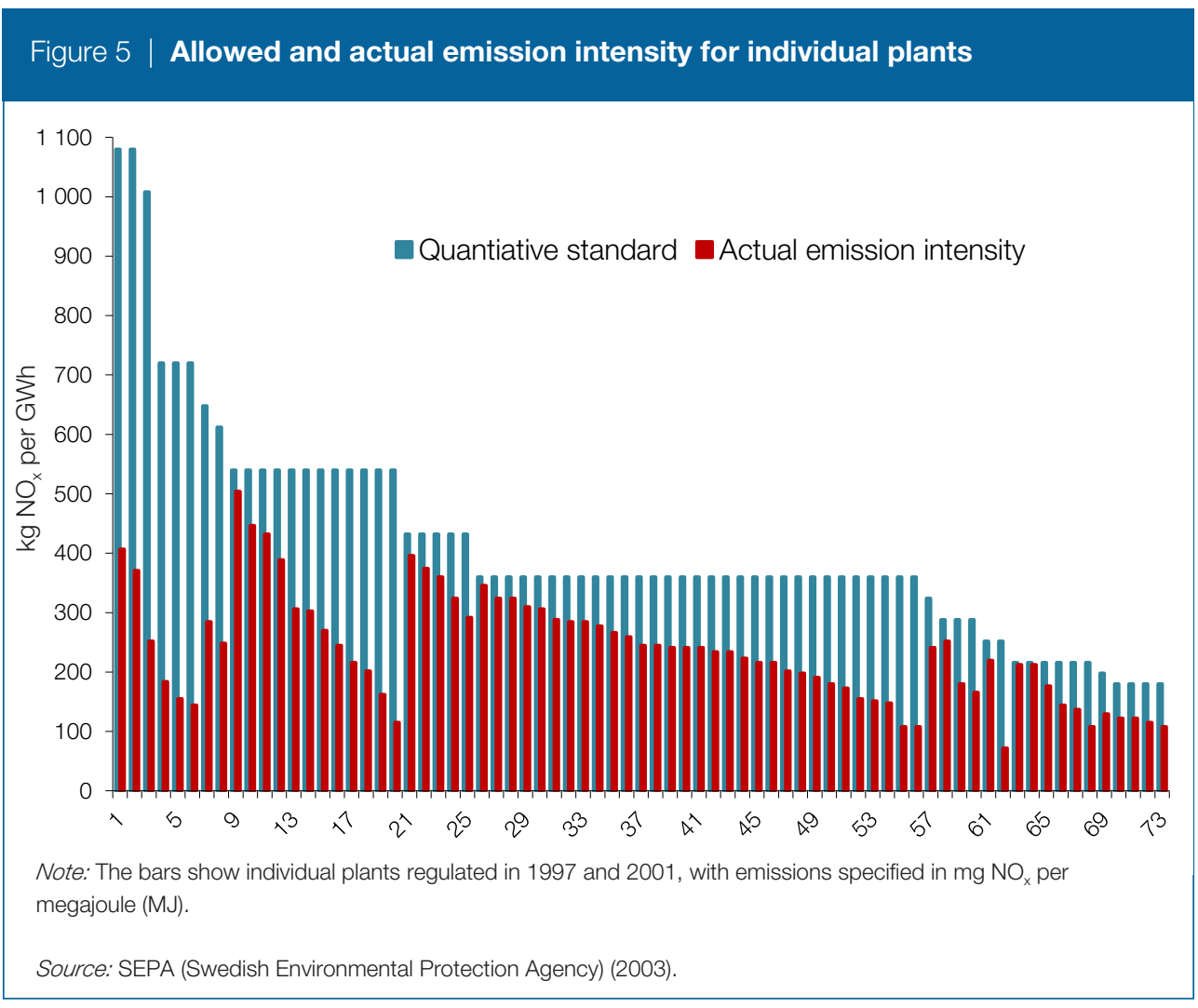

10. Forty per cent of all firms included in Figure 5 had a permit to emit $100 \mathrm{mg} \mathrm{NO}_{x}$ for every megajoule $(\mathrm{MJ})$ of energy they produced.

11. The emission intensity is the average emission rate of a given pollutant from a given source relative to the intensity of a specific activity; for example milligrams of $\mathrm{NO}_{x}$ released per megajoule of energy produced. 
Figure 6 indicates that the improvements in $\mathrm{NO}_{\mathrm{x}}$ emissions per unit have been most important in the firms with an energy production larger than $50 \mathrm{GWh}$ per year. For the firms with lower energy production, the emission intensity did decrease significantly the first year after taxation was introduced, but emissions since then have been more varied.

\section{Figure 6 | How $\mathrm{NO}_{\mathrm{x}}$ emissions per energy unit vary for firms of different sizes}

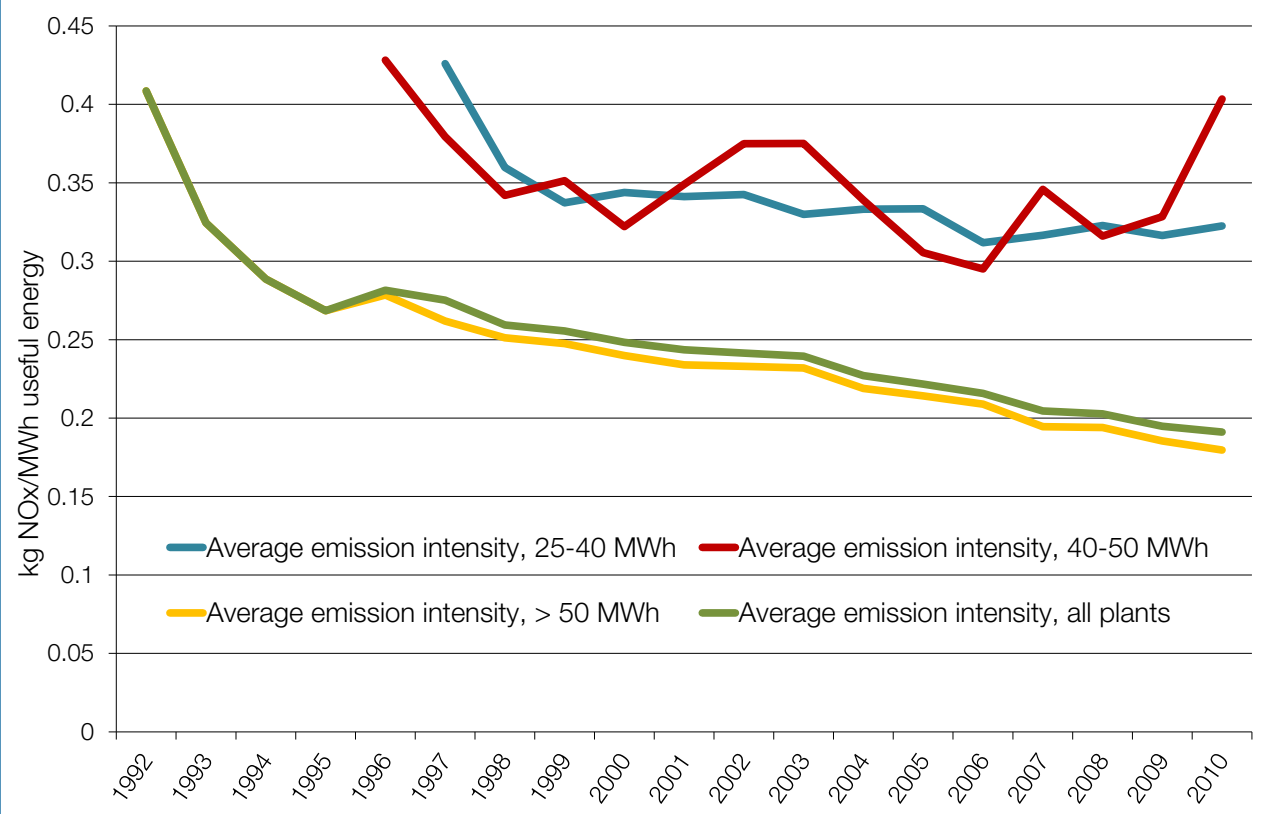

Source: Swedish Environment Protection Agency. 


\section{What's driving emission reductions?}

The reduction in emissions of $\mathrm{NO}_{\mathrm{x}}$ cannot solely be ascribed to the effect of the $\mathrm{NO}_{\mathrm{x}}$ tax system. A large number of boilers are also subject to specific regulations stipulated in the plants' operating permits under the Environmental Code (SEPA, 2006). They must also comply with parallel quantitative standards both for $\mathrm{NO}_{\mathrm{x}}$ and other pollutants, and emissions may also have fallen through cost-effectiveness activities unrelated to $\mathrm{NO}_{\mathrm{x}}$ reduction (Sterner and Höglund, 2005).

Lena Höglund-Isaksson and Thomas Sterner analysed 626 combustion plants that were regulated by the $\mathrm{NO}_{\mathrm{x}}$ tax for at least one year between 1992 and 2007 (OECD, 2010a). In Figure 7, the plants have been plotted in order of increasing emission intensities against the cumulative energy output of the plants. This illustrates how emission intensities in later years are considerably lower than in 1992 when the tax was introduced. For example, in 1992, the plants were producing 3000 Gigawatt hours (GWh) of energy while emitting around $550 \mathrm{~kg}$ $\mathrm{NO}_{\mathrm{x}}$ per GWh. Sixteen years later, in 2007, the plants were able to produce the same amount of energy while emitting less than $181 \mathrm{~kg} \mathrm{NO}$ xer $\mathrm{GWh}$ - an improvement of $67 \%$. There are three main explanations for this:

- $\quad$ Cumulative energy output produced by the plants increased by $74 \%$ over the period. The expansion in output mostly took place in plants that were relatively emission-efficient.

- $\quad$ Regulated plants invested in $\mathrm{NO}_{\mathrm{x}}$ mitigation and were therefore able to produce more energy output with fewer emissions.

- Innovations in mitigation technology made it possible to reach even lower emission intensity levels for the same output level.

Some of these explanations are explored further below.

\section{Stimulating innovation}

The design of the Swedish $\mathrm{NO}_{\mathrm{x}}$ tax has stimulated demand for new technologies. It has done so through: (1) the refund system, which promotes competition to achieve the lowest $\mathrm{NO}_{\mathrm{x}}$ emissions per unit of energy produced; and (2) its requirement to install equipment to monitor $\mathrm{NO}_{\mathrm{x}}$ emissions on a continuous basis. This has driven demand for several new technologies for pre-combustion, combustion, post-combustion and monitoring, as well as energy efficiency (OECD, 2010a). 


\section{Figure 7 | How emission intensity has improved in plants covered by the NO $\mathrm{x}_{\mathrm{x}}$ tax}

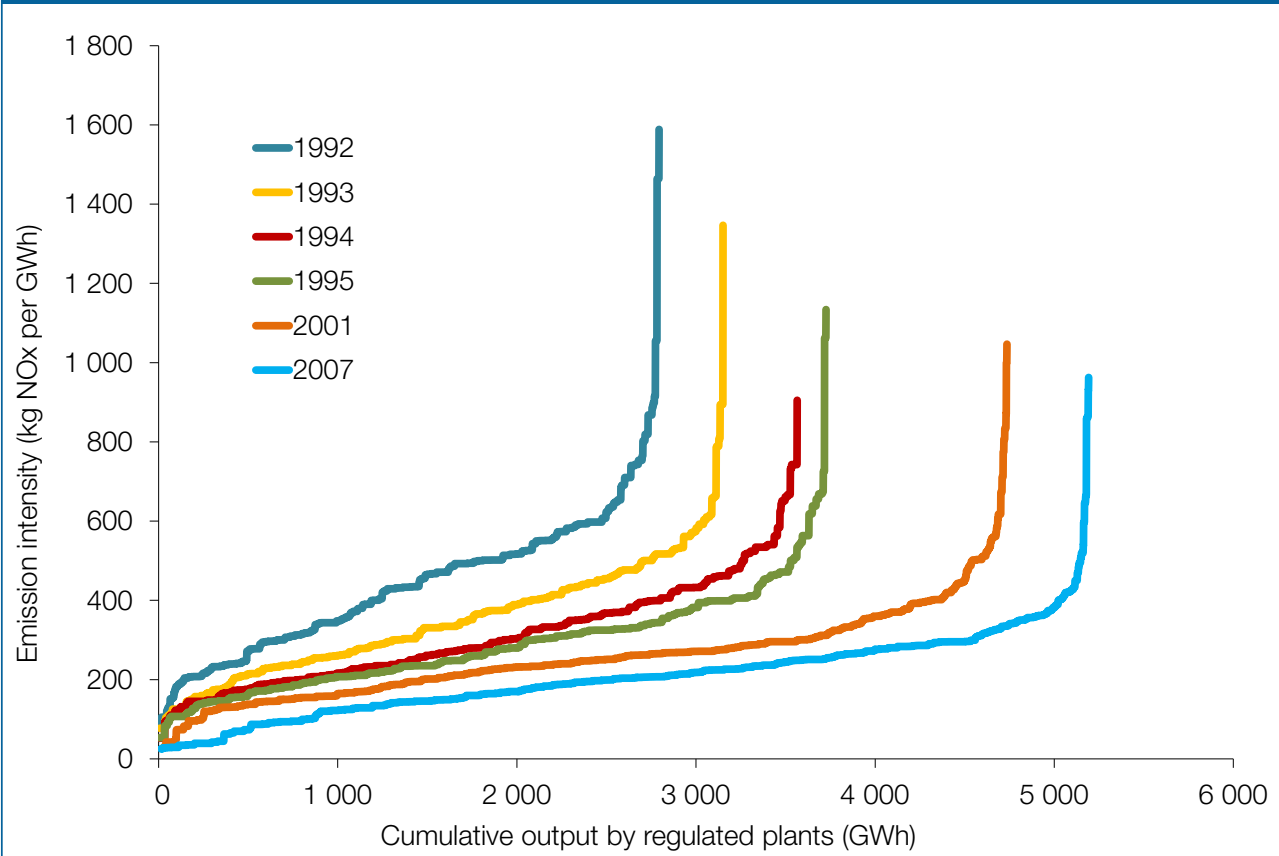

Source: SEPA (Swedish Environmental Protection Agency) (2008), Database of Information from Annual Surveys of Plants Regulated by the Swedish $\mathrm{NO}_{x}$ Charge, SEPA, Östersund.

The impact of the tax on innovations for reducing $\mathrm{NO}_{\mathrm{x}}$ emissions has been studied by the OECD (OECD, 2010a and 2010b). In 1992 - the year the tax was introduced - only 7\% of the plants subject to the $\mathrm{NO}_{\mathrm{x}}$ tax reported to the Swedish Environmental Protection Agency (SEPA) that they had $\mathrm{NO}_{\mathrm{x}}$ abatement technologies installed. A year later, $62 \%$ of plants reported having some kind of $\mathrm{NO}_{\mathrm{x}}$ abatement technology installed, and this share increased to $72 \%$ in 1995 . An analysis of patents lodged for combustion and post-combustion technology shows that in Sweden there appears to have been continuous activity in this field since 1988, especially between 1988 and 1993. The intense activity during this particular period coincides with the introduction of quantitative standards for $\mathrm{NO}_{\mathrm{x}}$ in 1988 and the $\mathrm{NO}_{\mathrm{x}}$ charge in 1992.

\section{6}

With quantitative emission standards there is no cost saving to be made from reducing emissions further, once the standard has been met and, hence, there are no further incentives for innovations. 
In a survey of plants included in the first five years of the tax, Höglund-Isaksson (2005) found that the adoption of $\mathrm{NO}_{\mathrm{x}}$ control technologies was a combined effect of the tax and the individual emission standards that the plants had been subject to since 1988. She found that out of $162 \mathrm{NO}_{\mathrm{x}}$-reducing measures undertaken, $47 \%$ would not have been implemented without the introduction of the tax, 22\% were undertaken primarily to meet the quantitative standards, and 31\% primarily for other reasons, e.g. improved cost-effectiveness (unrelated to $\mathrm{NO}_{\mathrm{x}}$ reductions) or compliance with emission standards for other pollutants than $\mathrm{NO}_{\mathrm{x}}$ (predominantly $\mathrm{SO}_{2}$ ). Thus, the $\mathrm{NO}_{\mathrm{x}}$ tax appears to have been the most important, but not the only, factor for $\mathrm{NO}_{\mathrm{x}}$ abatement adoption during this first phase of the $\mathrm{NO}_{\mathrm{x}}$ tax and refund system.

However, while the $\mathrm{NO}_{\mathrm{x}}$ tax clearly stimulated innovation, a regulated firm's willingness to share innovations with other regulated plants is hampered by the refund system, since a spread of the innovation to other regulated firms will reduce the innovating firm's own tax refund. On the other hand, for firms producing $\mathrm{NO}_{\mathrm{x}}$ emission abatement equipment - who are not themselves directly affected by the $\mathrm{NO}_{\mathrm{x}}$ tax - there are no such obstacles.

\section{Economic impacts}

The net winners and losers among the firms in the different industrial sectors covered by the tax in 2010 are illustrated in Figure 8. Each vertical bar in the graph represents a separate firm. The bars showing positive values represent

66

The introduction of the tax revealed abatement opportunities to pick the "low-hanging fruit". firms that receive more in refund than what they paid in taxes - the "winners" in the system. While there are "winners" and "losers" in all sectors, the "losers" are largely from the pulp-and paper ${ }^{12}$ and wood industry - but the net tax payments per firm are relatively modest. There are a few large "winners" in the combined heat and power generation sector - with one plant receiving about SEK 27 million, or more than EUR 3 million in net refund.

12. Possibly for this reason, the pulp and paper sector at one stage suggested that the refund system should be changed, in such a way that each sector received a refund equal to the total tax payments from that sector (with a deduction for administrative costs). This proposal was, however, not adopted. 


\section{Figure 8 | The Swedish NO $_{\mathbf{x}}$ tax: winners and losers by sector}

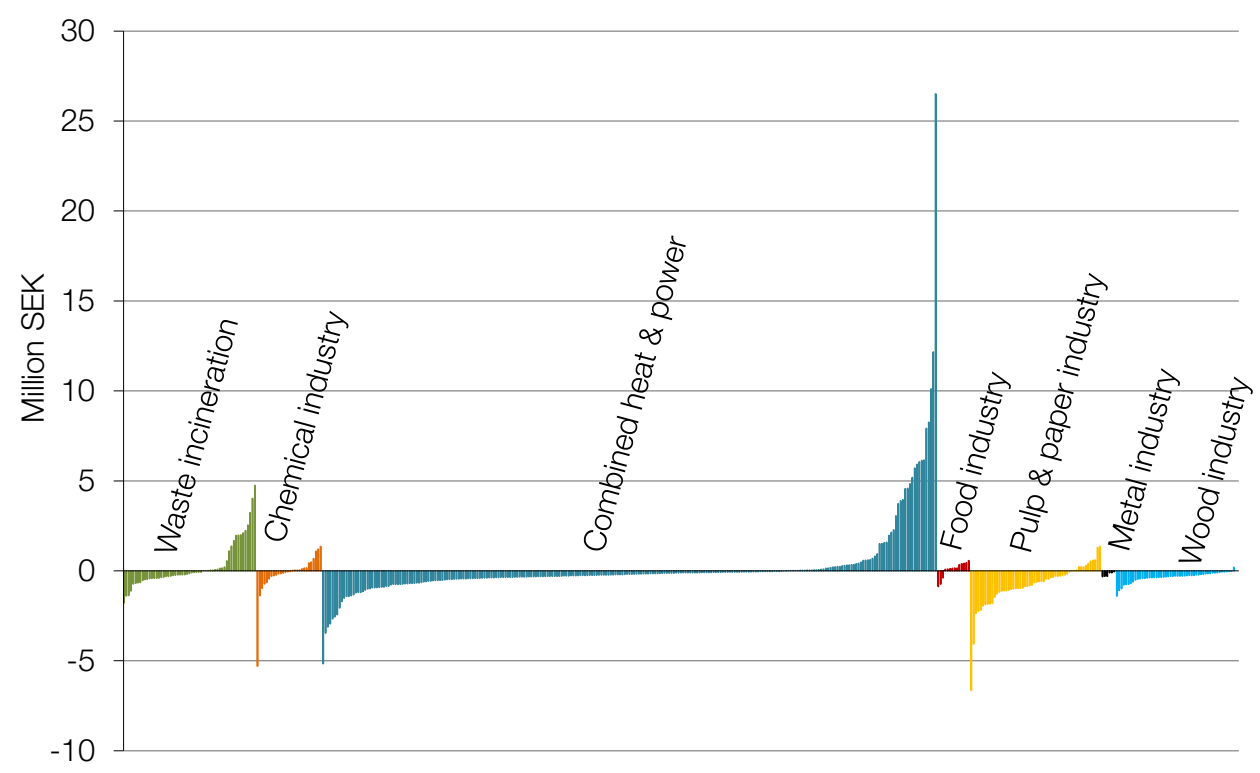

Source: Swedish Environment Protection Agency.

\section{Costs of emission reduction for affected facilities}

According to SEPA (2006), comparatively large $\mathrm{NO}_{\mathrm{x}}$ emission reductions have been possible at zero or very low cost. In 1996, the average cost of measures to reduce emissions as a result of the $\mathrm{NO}_{\mathrm{x}}$ tax was SEK 7.5 (about EUR 0.8) per kg of reduced $\mathrm{NO}_{\mathrm{x}}$. Reduced emissions at zero cost or even at a profit were reported for about $30 \%$ of boilers. One reason for this may be that the implementation of $\mathrm{NO}_{\mathrm{x}}$ abatement measures has often been preceded by thorough scrutiny of the boilers and their functions, highlighting opportunities for efficiency-improving and cost-saving measures. The $\mathrm{NO}_{\mathrm{x}}$ tax has also increased knowledge of abatement measures (SEPA, 2006). 
Analysis of 114 plants regulated between 1992 and 1996 found that the emission intensity attainable at no extra cost decreased from $557 \mathrm{~kg}$ per GWh in 1991 to about 300 kg per GWh in 1996 (Figure 9; Höglund Isaksson, 2005). This shift likely comes from adoption of innovations in abatement technology, which made it possible to produce energy with less $\mathrm{NO}_{\mathrm{x}}$ emissions but without increasing costs. To a large extent, the effects are referred to as trimming activities. Some of these opportunities also existed before the introduction of the tax; however, the tax's requirement to measure $\mathrm{NO}_{\mathrm{x}}$ emissions continuously made it possible for the firms to discover and develop them to attain even lower emission intensity levels.

The figure also shows that for a firm with an emission intensity of $200 \mathrm{~kg}$ of $\mathrm{NO}_{\mathrm{x}}$ per GWh in 1991, the cost of reducing emissions by one kg (i.e. the marginal abatement cost) was close to SEK 130 (about EUR 13.5). In 1996, this cost had fallen to less than SEK 20.

\section{Figure 9 | Falling $\mathbf{N O}_{\mathrm{x}}$ abatement costs in the energy sector in Sweden}

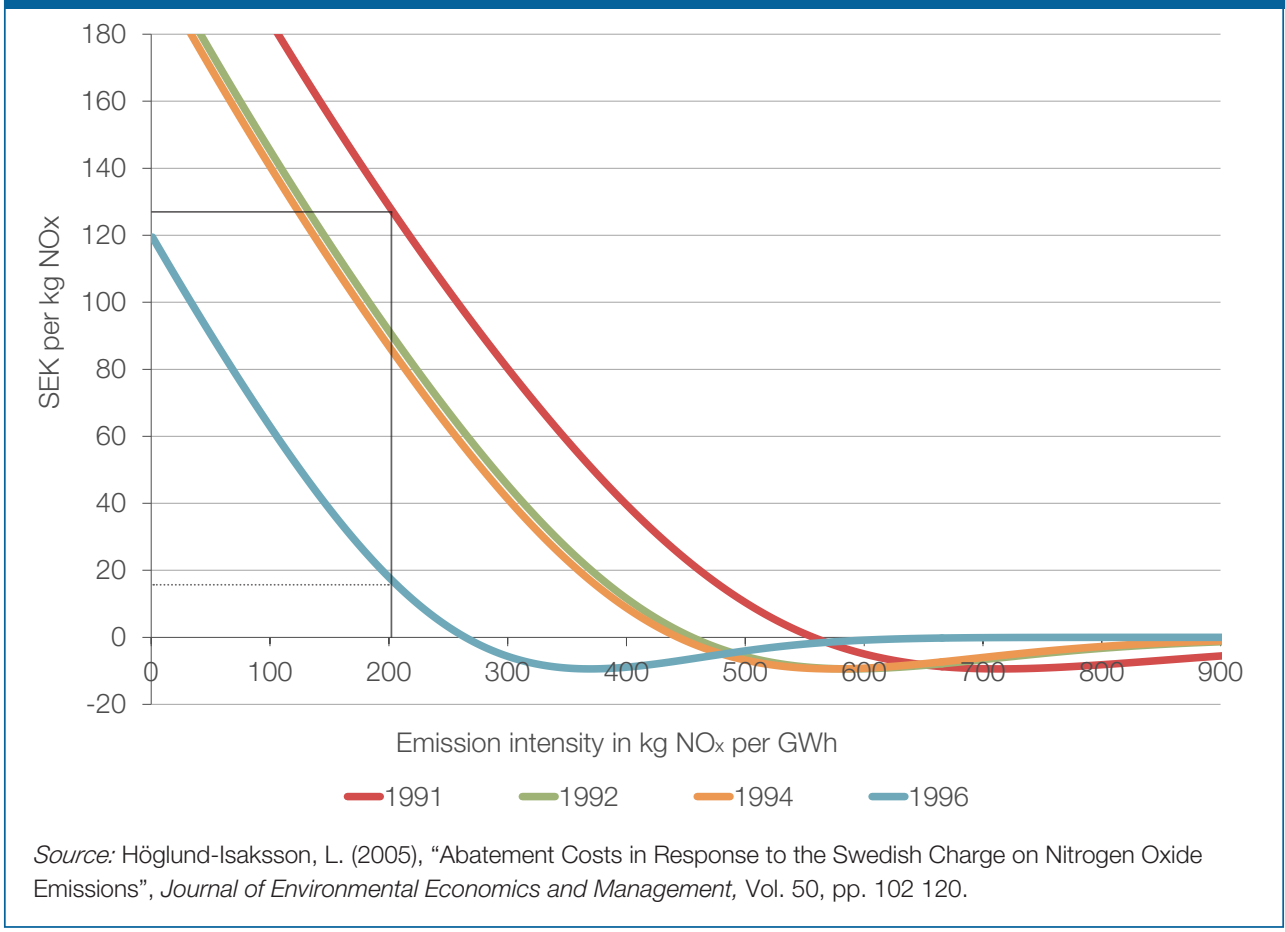




\section{Economy-wide costs}

Apart from the direct abatement cost for the plants, what are the wider costs of the tax? Based on a survey of 114 plants regulated by the $\mathrm{NO}_{\mathrm{x}}$ tax between 1992 and 1996, Höglund (2000) estimated the average total cost to be between SEK 25 and 40 for every kilogramme of $\mathrm{NO}_{\mathrm{x}}$ reduced. Splitting the total costs of the $\mathrm{NO}_{\mathrm{x}}$ tax into detailed cost components (Table 1 ) revealed that abatement costs make up about $50 \%$ of total costs, or SEK 12 to 25 per $\mathrm{kg}$ of reduced $\mathrm{NO}_{\mathrm{x}}$ emissions, depending on the assumed lifetime of fixed investments. Monitoring costs, including annual calibration of monitoring equipment, were estimated at 140000 to 193000 SEK per plant per year, or about $20 \%$ of total costs. Administration costs were found to be low. About $2 \%$ of total costs were spent on additional administration within plants and $1 \%$ on administration by SEPA, according to this study.

$\mathrm{NO}_{\mathrm{x}}$ abatement often gives rise to increased emissions of other pollutants, like carbon oxide (CO), nitrous oxide $\left(\mathrm{N}_{2} \mathrm{O}\right)$ and ammonia $\left(\mathrm{NH}_{3}\right)$, as by-products of the incomplete break-down of $\mathrm{NO}_{\mathrm{x}}$ or residuals of additives used, depending on the abatement technology applied. Although estimating the damage costs of these pollutants to society is difficult, Höglund (2000) made an attempt using estimates by SEPA (1997). The cost to society of emission increases in these pollutants was found to represent about $23 \%$ of total costs to the Swedish economy. Finally, the refund mechanism gives rise to a welfare loss due to distortions in resource allocation (for further details, see Social Impacts section below), which was estimated at about SEK 1 per $\mathrm{kg} \mathrm{NO}_{\mathrm{x}}$ reduced, or $3 \%$ of total average costs. The cost components are summarised in Table 1.

\section{Table 1 | Relative contribution of different components to the total cost} of the Swedish $\mathrm{NO}_{\mathrm{x}}$ tax

\begin{tabular}{|c|c|}
\hline COST COMPONENT & \\
\hline $\mathrm{NO}_{x}$ abatement & $50 \%$ \\
\hline Monitoring and compulsory calibration of monitoring equipment & $20 \%$ \\
\hline Plant administration & $2 \%$ \\
\hline Regulator administration & $1 \%$ \\
\hline Increased emissions of $\mathrm{CO}, \mathrm{VOC}, \mathrm{N}_{2} \mathrm{O}$ and $\mathrm{NH}_{3}$ & $23 \%$ \\
\hline Distorted resource allocation due to refunding & $3 \%$ \\
\hline Total (25 to 40 SEK per kg NO reduced) $^{2}$ & $100 \%$ \\
\hline
\end{tabular}

Source: Höglund, L. (2000), Essays on Environmental Regulation with Applications to Sweden, Ph.D. thesis, Department of Economics, Gothenburg University, Sweden. 


\section{Competitiveness impacts}

As mentioned above, the significant costs involved in continuous monitoring of $\mathrm{NO}_{\mathrm{x}}$ emissions meant that authorities had to set an energy production threshold below which a firm was exempted from the tax. This was deemed to be important for the competitiveness of district heating compared to individual heating in homes and offices. This has been addressed by the refund system already described, but also by reducing the threshold value twice, from originally $50 \mathrm{MWh}$ of useful energy per year to $25 \mathrm{MWh}$ of useful energy per year - partly in response to the development of cheaper measurement technologies. The lower the threshold, the broader the coverage of the tax - and the smaller the competitiveness problems in relation to firms that are not covered.

\section{Social impacts}

Due to the refund mechanism, there was hardly any net cost increase for industry, and hence virtually no impacts on product prices. This in turn meant that there is no negative income distribution impact from the scheme.

However, this is also one of the disadvantages of a refunded tax: by having little impact on the relative prices of products whose production involved high emissions, it does not discourage demand for such products. ${ }^{13}$ For the same reasons, it would be very difficult to achieve a fundamental decarbonisation of the economy if one only were to rely on taxes where for example electricity generators and other industries had their tax payments refunded in one way or another.

The main drawback with refunding is that it preserves an already distorted resource allocation. The refund resembles a subsidy from society to the producers. Polluters do not pay the full environmental cost of the pollution their production causes. This leads to a welfare loss to society since too much productive resources are allocated to polluting production relative to cleaner production. Hence, the polluter pays principle does not apply when emission charges are refunded to polluters (OECD, 2010a). 


\section{Comparison with other countries}

How does the environmental effectiveness and economic efficiency

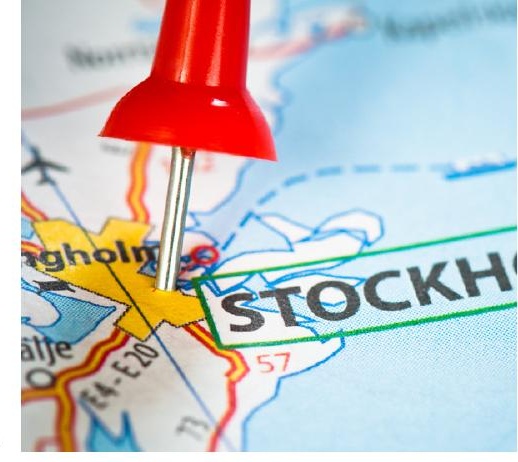
of the Swedish $\mathrm{NO}_{\mathrm{x}}$ tax compare with policy instruments applied in other countries?

Figure 10 shows how much $\mathrm{NO}_{\mathrm{x}}$ was emitted per unit of electricity and heat produced by fuel combustion ${ }^{14}$ in electricity generation and industry across OECD countries in 1995 and 2000 compared to 1990 levels. Sweden performs well in comparison to most OECD countries, especially when considering that the country's emissions per energy unit at the outset were already among the lowest. ${ }^{15}$ Even starting from a strong position, the $\mathrm{NO}_{\mathrm{x}}$ emissions per unit energy produced in 2000 were $40 \%$ of their 1990 levels.

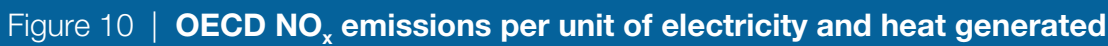

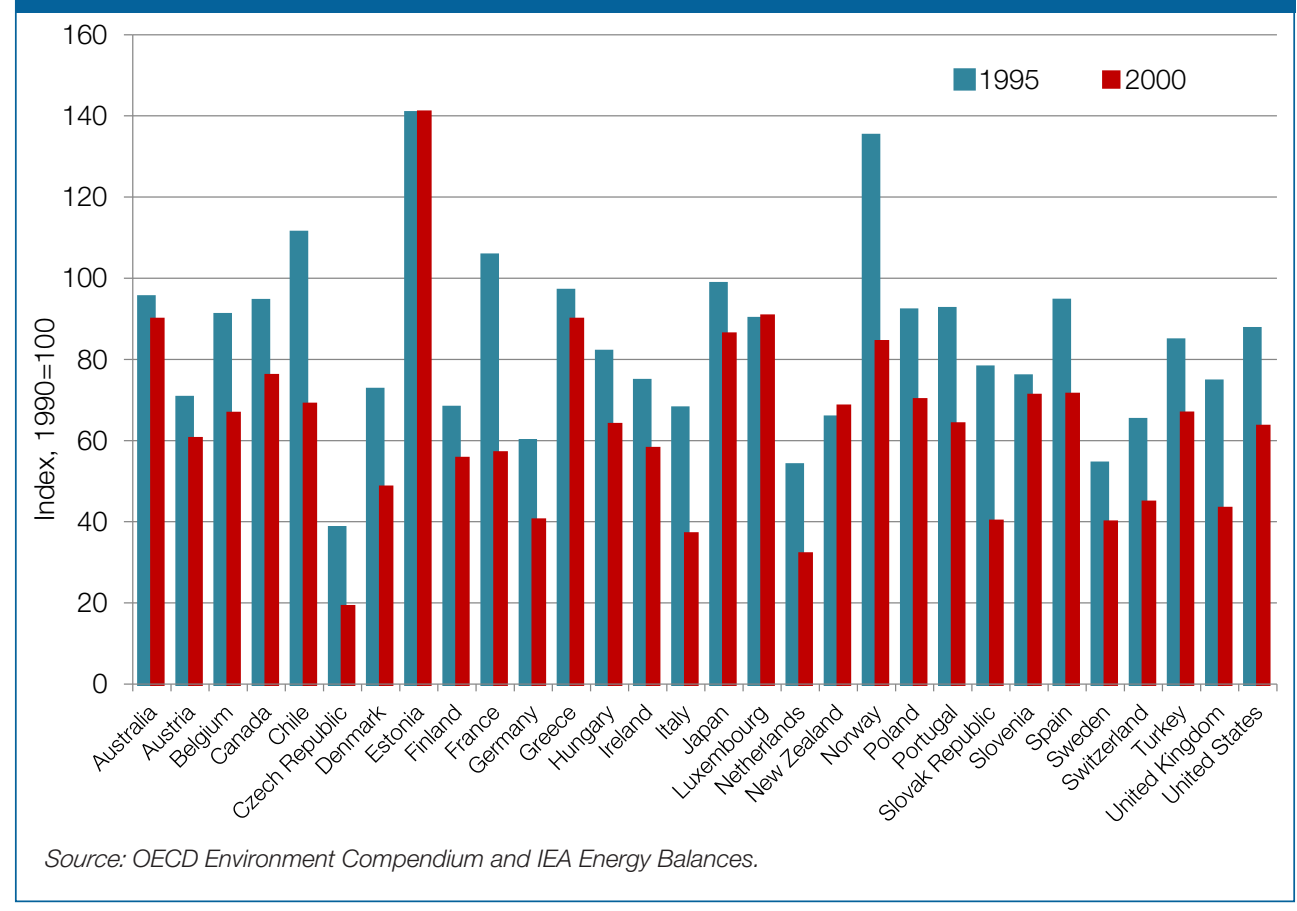

14. The comparison only includes electricity and heat produced by combusting fuels. Hence, electricity generated by hydro power or in nuclear power plants is excluded - as this would not generate any $\mathrm{NO}_{x}$ emissions.

15. A country like the Czech Republic started out with several times the $\mathrm{NO}_{\mathrm{x}}$ emissions per energy units produced of Sweden, as their emission reductions across the 1990s were facilitated by the major economic restructuring the country went through in those years. 
What is lacking in the comparison is information about the costs of the different policy measures. Unfortunately, the data necessary for a comprehensive comparison over the relevant years are not available, although there are some data for a few European countries (Box 3).

\section{Box 3 | What do other countries do?}

In 2007 and 2010, Norway and Denmark introduced taxes on $\mathrm{NO}_{x}$ emissions at rates of EUR 2.1 and EUR 0.7 per $\mathrm{kg} \mathrm{NO}_{x}$ respectively. These had a broader sectoral coverage than in Sweden, but did not include a refund system. The Danish tax rate was increased to EUR 3.4 per $\mathrm{kg} \mathrm{NO}_{x}$ in July 2012. The tax rate applied in Norway is based on an estimate of the value of the damage caused by one $\mathrm{kg}$ of $\mathrm{NO}_{x}$ emitted. However, strong industry opposition in Norway has led to exemptions for emission sources covered by environmental agreements with the state concerning the implementation of measures to reduce $\mathrm{NO}_{x}$ in accordance with a predetermined environmental target. Taxes on $\mathrm{NO}_{x}$ emissions have also been introduced in several other countries - such as France, Italy and Galicia in Spain - but in most cases, the tax rates are quite modest.

The French tax on $\mathrm{NO}_{x}$ emissions was introduced in 1990 as part of a combined package to reduce emissions of the air pollutants $\mathrm{SO}_{2}, \mathrm{NO}_{x}$ and $\mathrm{VOC}$ from large combustion plants. Revenues from the charge were destined to subsidise investments in abatement technology in regulated plants and for research and development of abatement technology. Due to concerns about distortions in competitiveness, the tax rate was set very low - about $1 \%$ of the Swedish $\mathrm{NO}_{x}$ charge. There was also no requirement for continuous monitoring of emissions. Both factors are mentioned by Millock, Nauges and Sterner as important explanations for why the French $\mathrm{NO}_{x}$ tax did not have any measured effect on $\mathrm{NO}_{x}$ emissions (cited in OECD, 2010a). 


\section{Lessons learned}

The Swedish case demonstrates clearly that well-designed economic instruments that provide significant economic abatement incentives can trigger important environmental improvements. It also demonstrates that such instruments can strongly encourage innovation - which helps to lower the costs over time of achieving ambitious environmental policy objectives. Lessons with wider applicability include:

- $\quad$ A high emissions tax rate can be made politically acceptable by refunding the money earned back to the sector: this strongly reduces the total cost to the affected polluters and hence the resources they will expend on lobbying to stop or lower the charge (Sterner and Höglund, 2006). The decision to

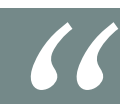

With less resistance from polluters it becomes politically easier to set environmental taxes that are high enough to generate substantial environmental improvements. exclude smaller plants was based partly on the high costs of metering which (together with abatement costs) were considered unreasonable for smaller plants. If a tax without refunds had been applied to only a subsection of some industry then this would have been unfair compared to other firms in the same industry. In this case, if the tax were applied only to the large plants, companies would have an incentive to set up several small combustion plants instead of one big one and this is typically not desirable (from any viewpoint including emissions of $\mathrm{NO}_{\mathrm{x}}$ and other pollutants).

- Well-focussed environmental information to the public at large can play an important role. The introduction of the tax was also most likely helped by the good understanding by many Swedes of the environmental damage caused by $\mathrm{NO}_{\mathrm{x}}$ emissions and of the potential benefits of using economic policy instruments in environmental policy.

- $\quad$ A policy designed with the involvement of all parliamentary parties - as was the case with Sweden's Environmental Charges Commission - is likely to contribute to broad support. 
- $\quad$ Continuous (and correct) measurement of emissions is important for bringing attention to low-cost emission reductions that can be achieved simply by "trimming" production processes. In a number of countries, continuous measurement of a broad spectrum of pollutant emissions is now compulsory for many sources. This could form the basis for the more widespread use of economic instruments.

- $\quad$ Measures to abate $\mathrm{NO}_{\mathrm{x}}$ emissions can increase emissions of other pollutants, such as $\mathrm{CO}, \mathrm{VOC}, \mathrm{N}_{2} \mathrm{O}$ and $\mathrm{NH}_{3}$. This phenomenon is not due to the use of a tax instrument as such, but could occur as a result of any measure taken in response to almost any type of policy instrument. While possible increases in other emissions in principle could be addressed via a number of policy instruments, a promising and consistent alternative would be to introduce a "price" on each of the linked pollutants, reflecting their relative damage to society.

This is one of the few OECD examples of a tax or charge that is refunded directly in this way, and offers an interesting alternative to permits, particularly when the regulator wants a price-type instrument but does not want to place the full cost burden on the polluters. For a small open economy in which trade-sensitivity is an issue, refunding makes political sense (Sterner and Höglund-Isaksson, 2006). 


\section{References}

Höglund, L. (2000), Essays on Environmental Regulation with Applications to Sweden, PhD thesis, Department of Economics, Gothenburg University, Sweden.

Höglund-Isaksson, L. (2005), "Abatement Costs in Response to the Swedish Charge on Nitrogen Oxide Emissions”, Journal of Environmental Economics and Management, Vol. 50, pp. 102120.

OECD (2010a), Innovation Impacts of the Swedish NOx Charge, OECD, Paris, available at www.oecd.org/ greengrowth/consumption-innovation/43211635.pdf.

OECD (2010b), Taxation, Innovation and the Environment, OECD Publishing. doi: 10.1787/9789264087637-en.

OECD (2008), Environmentally Related Taxes and Tradable Permit Systems in Practice, OECD, Paris, available at www.oecd.org/officialdocuments/displaydocumentpdf/?cote=com/env/epoc/ctpa/cfa(2007)31/final.

SEPA (Swedish Environmental Protection Agency) (2008), Database of Information from Annual Surveys of Plants Regulated by the Swedish NOx Charge, SEPA, Östersund.

SEPA (2006), The Swedish Charge on Nitrogen Oxides - Cost-effective emission reduction, SEPA, Stockholm, available at www.naturvardsverket.se/Documents/publikationer/620-8245-0.pdf.

SEPA (2003), Kväveoxidavgiften - ett effektivt styrmedel. Utvärdering av NOx-avgiften (Reducing NOx Emissions. An Evaluation of the NOx Tax), Swedish, with an English Summary, Rapport 5335, SEPA, Stockholm, available at www.naturvardsverket.se/Documents/publikationer/620-5335-3.pdf.

SEPA (1997), "Kväveoxider från förbränning" (Nitrogen Oxide Emissions from Combustion), Allmänna råd 98:1, Swedish Environmental Protection Agency, Naturvårdsverket Förlag, Stockholm.

Sterner, T. and L. Höglund-Isaksson (2006), "Refunded Emission Payments Theory, Distribution of Costs, and Swedish Experience of $\mathrm{NO}_{x}$ Abatement", Ecological Economics, Vol. 57, pp. 93- 106.

Sterner, T. and B. Turnheim (2008), "Innovation and Diffusion of Environmental Technology", Discussion Paper 2008:02, Resources for the Future, Washington, DC, available at www.rff.org/RFF/Documents/ RFF-DP-08-02.pdf.

UCD (University College Dublin) (2008), Economic Instruments in Environmental Policy, webpage, www. economicinstruments.com/index.php/air-quality/article/73- accessed 8 April 2013. 
THE SWEDISH TAX ON NITROGEN OXIDE EMISSIONS: LESSONS IN ENVIRONMENTAL POLICY REFORM 


\section{The Swedish Tax on Nitrogen Oxide Emissions}

\section{Lessons in Environmental Policy Reform}

\section{The OECD Environment Policy Papers}

Designed for a wide readership, the OECD Environment Policy Papers distil many of today's environment-related policy issues based on a wide range of OECD work. In the form of country case studies or thematic reviews across countries, the Papers highlight practical implementation experience. They are available in either English or French, with a summary in the other language when possible.

1. OECD (2013), “Climate and Carbon: Aligning Prices and Policies”, OECD Environment Policy Papers, No. 1, OECD Publishing. doi: 10.1787/5k3z11hjg6r7-en.

2. OECD (2013), "The Swedish Tax on Nitrogen Oxide Emissions: Lessons in Environmental Policy Reform", OECD Environment Policy Papers, No. 2, OECD Publishing.

\section{Acknowledgements}

This case study is based on an earlier OECD paper prepared by Nils Axel Braathen under a project of the OECD Working Party on Integrating Environmental and Economic Policies on political economy of environmental policy reforms. The Swedish Environmental Protection Agency kindly provided data used therein. 